Power relations and the production of new knowledge within a Queensland Music Festival community cultural development project

Raphaela Stadler

PhD Candidate

Department of Tourism, Leisure, Hotel and Sport Management

Griffith Business School

Business 2 (N72), Room 0.17

Nathan campus, Griffith University

170 Kessels Road, Nathan QLD 4111, Australia

$\mathrm{Ph}:+61737355491$

Email: r.stadler@griffith.edu.au 


\section{Power relations and the production of new knowledge within a Queensland Music}

Festival community cultural development project

\section{Abstract}

Conflict during the creative development process of community cultural development projects is inevitable (Adam \& Goldbard, 2001), yet through the productive use of power (Foucault, 1977, 1980, 1982), new knowledge can be created for the festival organisation, the community and individual participants. In this article I identify power/knowledge relations within the Queensland Music Festival community cultural development project Behind the Cane, a three-year project with the South Sea Islander community in Bowen, Queensland, Australia, through a narrative analysis of different stories that my participants told about the project. These stories emphasise strategic and disciplinary power during the creative development process of Behind the Cane, as well as the power of the story and the performance itself and what it meant to the local community and the festival organisation. From these stories I explain how new knowledge was created within the community as well as the festival organisation.

Keywords: power/knowledge, community cultural development, festival organisations, stories

\section{Introduction}

The importance of community festivals and community music making has become a popular topic of research in recent years (Kay, 2000; Mulligan \& Smith, 2006; Hager, 2008; Duffy \& Waitt, 2011; Gibson, Connell, Waitt, \& Walmsley, 2011: Gibson \& 
Connell, 2012). The value of these initiatives can be very high, not only for participants but also the broader community and stakeholders (i.e. partnerships, networking, building social capital). Amongst the key outcomes of these events are not only economic benefits for the community, but also social outcomes in terms of developing new skills and knowledge, learning about issues within the community and bringing the community closer together through a shared leisure experience (Adam \& Goldbard, 2001; O'Rourke, Irwin, \& Straker, 2011). However, the process of engaging the community and creating artistic performances with them rather than imposing ideas upon them can be a challenge for practitioners and festival organisers (Bramham, 1994; Clarke \& Jepson, 2011).

Getz (2007: 307) argued that, '[t]he extent to which residents are involved with events, from volunteering to ownership, and including citizen power to influence the decisionmaking process, can determine or moderate many social, cultural and political outcomes.' I address this issue by looking at power/knowledge relations and the creation of new knowledge through a community cultural development project commissioned and presented by the Queensland Music Festival (QMF) in 2011. Power relations in festivals and community empowerment have been explored by Clarke and Jepson (2011) and Cole (2006) respectively, however, I argue that not only the festival organisation can exercise disciplinary power (Foucault, 1977, 1980), but also the community. In this article, I identify different stories that my participants told about the Queensland Music Festival project Behind the Cane - a project about the 'blackbirding' history in Queensland, Australia, where thousands of South Sea Islanders were kidnapped to work on sugar cane farms in Queensland during the second half of the $19^{\text {th }}$ century (Wawn, 1973). For a deep analysis of the issue, it is also important to understand the meaning 
behind stories (Sinclair, 2005) and I explore these meanings, not only for my participants but also the broader community and the festival organisation. I argue that conflict in the creative development process is inevitable, yet through the productive use of power, new knowledge can be created for the festival organisation, the community and individual participants.

\section{Community cultural development}

Community cultural development describes 'a range of initiatives undertaken by artists in collaboration with other community members to express identity, concerns and aspirations through the arts (...), while building cultural capacity and contributing to social change' (Adam \& Goldbard, 2001: 107). The community arts and community cultural development movement therefore emphasise including disadvantaged and culturally different groups of people, to make their voices heard through the arts and music. The central aim is to move away from 'high culture' and the centre of arts production towards greater engagement with the periphery and regional communities. Furthermore, all citizens, not merely the 'elite', should have access to art and culture (Hager, 2008). Community cultural development programmes therefore concentrate on production, rather than mere consumption of art (Hawkins, 1991), as well as on the development of new skills and knowledge within the community (Martin, Tunny, \& Carroli, 2000; Sonn, Drew, \& Kasat, 2002; Derrett, 2003; Bartleet, Dunbar-Hall, Letts, \& Schippers, 2010).

Most of the long-term value of community cultural development initiatives is noneconomic and therefore difficult to measure (Molloy, 2002; Gibson, et al., 2011). Some 
long-lasting effects are individual, such as personal development of new skills, becoming interested in new topics, making new friends and sharing the rehearsal and performance experience (Adam \& Goldbard, 2001; Sonn, et al., 2002; Bartleet, et al., 2010). Other effects are positive for the community as a whole, as for example an enhanced image of the community, more positive feelings about where community members live, and pride in their local identity. Furthermore, networks with other institutions and communities can be built or enhanced through partnerships and collaboration (Hawkins, 1991; Kay, 2000; Carey \& Sutton, 2004; Reid, 2008; Lancaster, Kyte, Craik, \& Schippers, 2010; Gibson \& Connell, 2012). Arts projects that are 'owned' by the local community are most effective (Kay, 2000: 423). They have to be of value for the community, in order to create a collective identity among community members.

These changes in the perception of the role of art in culture in recent years led to an increase in community cultural development projects and participation in the arts (Hoffie, 1991; Hull, 1991; Kirby, 1991), particularly in Australia with its rich Aboriginal culture that is only slowly starting to be recognised by the wider Australian population (Phipps, 2011). Festivals by or with Indigenous communities can help convey their history, rituals and sense of place (Phipps \& Slater, 2010; Slater, 2011), as well as create an understanding of different cultural practices beyond the Australian city centres. The Australia Council for the Arts (2010: 40) reported that '[o]f the 80 per cent of people who had creatively or receptively participated in visual arts and crafts, theatre, dance, creative writing or music in the past 12 months, a third ( 32 per cent) of them engaged in some form of community art.' The importance of community engagement in the arts was recognised as a valuable leisure experience, however, the same report highlighted that resi- 
dents of regional Australian communities still lacked opportunities for participation in the arts (Australia Council for the Arts, 2010).

The role of music in community cultural development programmes can have a significant effect on the local community. Not only can music create a sense of belonging and identification with a particular city, town or region (Bennett, 2005), but also the use of a certain musical style in the performance can enhance participants' understanding of the story (Cohen, 1995). Furthermore, the process of rehearsing the songs and scenes together and being part of the production can bring about a feeling of belonging to the group and thus social inclusion (Pitts, 2005). Sharing this leisure experience and other social rituals associated with it, such as going out for drinks after rehearsals, can create and foster friendships as well as a common experience and a feeling of 'being in this together'. This is particularly valuable among amateur performers (Bennett, 2005; Pitts, 2005). Arts practitioners and festival organisers, therefore, need to understand that the process of developing the performance together with the community and of rehearsing with them is an important part of creating a sense of belonging and identification with the work, as well as developing new friendships and skills.

\section{Power/knowledge}

Foucault $(1978,1980,1982)$ argued that neither power nor knowledge can be defined as a 'thing', but rather as a complex relation. Power produces different kinds of knowledge, which in turn influence exercises of power. In this sense, power is not used in a repressive way, but rather productively and strategically. Power is not a property that somebody holds over somebody else, but rather a relation that operates at all differ- 
ent levels of the social body. According to Foucault $(1977,1982)$, discipline, for example, is one way that power can be exercised. Disciplining people's behaviour in society through mechanisms of organising space, time and people's activities is thereby regarded as exercising power. Rather than exercising power 'over' people, it is through these disciplinary practices that people come to live by certain standards or norms in society (Foucault, 1977; Clegg, 1998). A document, photo, ritual or story can thus also be instruments of power through which new knowledge can be created (Rouse, 2006). Forms of knowledge, at the same time, can function as indicators of what is normal and acceptable within an organisation, as well as what is not acceptable (Alvesson, 1996). Knowledge and power are thus inseparable.

In their study about power and hegemony within a community festival, Clarke and Jepson (2011) found that, on the one hand, the Steering Group of the festival exercised disciplinary power as they restricted the community's knowledge about culture and aimed for a high 'quality' event. On the other hand, the local communities were not directly involved in all decision-making processes throughout the planning of the festival. The authors argued that, even though not entirely intended, this exercise of power resulted in the communities not being able to feel ownership of the festival. The key to community cultural development projects and festivals, however, is that they 'must be delivered in a manner that involves and includes local people as partners in the process' (Carey \& Sutton, 2004: 133). A challenge in community cultural development programmes is that festival timelines for funding or other requirements 'can place restrictions on a creative process that by nature may need to remain flexible' (Mulligan \& Smith, 2006: 50). At the same time, the community may run on a different schedule, which in turn influences and is influenced by power relations during the project development process. Cole 
(2006) argued that through empowering the community, a shift in power balance from one group to another can be achieved; however, participation in the project alone is not enough to ensure participants' empowerment (Johnson, Glover, \& Yuen, 2009).

In this study I aimed to identify power/knowledge relations in community cultural development programmes and the QMF project Behind the Cane in particular. Power relations need to be considered in the process of knowledge creation (Bevir, 1999) and for the purpose of this article, particular consideration is given to power relations between the festival organisation and the community, as well as power relations within the $B e$ hind the Cane story itself. I analyse examples of such power relations in my participants' stories about the Behind the Cane project by identifying different views about the same project. I also identify the festival organisers' way of dealing with issues and challenges.

Dealing with a similar topic, I aim to further Casbeard's (2010) argument that controversial historic events are not always (re)presented in a way that fulfils the interests of all stakeholders. Particularly marginalised voices are often included but misrepresented in remembering history. I argue, however, that collaborating and partnering with the local community during the creative development process of the work allowed them to make their own story heard, rather than QMF managers' interpretation of it. In analysing these power relations within an event that aimed to present a controversial historic practice I extend Casbeard's (2010) ideas of meaning, (mis)representation and inclusion.

\section{Behind the Cane}


The Queensland Music Festival (2011) vision is To transform lives through unforgettable musical experiences. This biennial music festival is based in Brisbane, Australia, but also offers several workshops, concerts and performances that involve local communities all over the state of Queensland. The festival organisers recognise the power of locally inspired stories that provide the basis for these community performances. Through the process of commissioning and presenting community projects, the QMF aims to generate a local sense of ownership and pride as well as a sense of unity among the community (QMF, 2011), which are central elements of community cultural development and community music making (Adam \& Goldbard, 2001; Bartleet, et al., 2010).

Behind the Cane was commissioned and presented by QMF in July 2011. This musical theatre piece was put together over the course of three years through partnership and collaboration between the festival organisation, the regional council and the South Sea Islander community in Bowen, Queensland, Australia. Bowen is a small town with a population of approximately 8,000 people located in North Queensland, between Townsville and Mackay. Behind the Cane told the history of thousands of South Sea Islanders being kidnapped ('blackbirded') and brought to Queensland to work on sugar cane farms between 1863 and 1906 (Docker, 1970; Wawn, 1973; Graves, 1993; Colbert, 1997). This topic was identified as 'a story that needs to be told' by the QMF artistic director, however, through interviews with members of the community the focus of the story later shifted to the survival of these people and how they are dealing with the issue today. Rather than emphasising the 'blackbirding' history itself, the piece was about the South Sea Islanders being proud of their ancestors, their story of survival and hard work. 
Including local residents in the show is an important aspect of community involvement in festivals (Rogers \& Anastasiadou, 2011). The QMF therefore took on the challenge of finding cast members who were direct South Sea Islander descendants. Almost all the cast on stage (except for a few 'white' cast members) were direct South Sea Islander descendants who now live in Bowen, representing their own family members in the show - their great great-grandparents, uncles or aunts. The aim was to tell their own story, all the challenges these families had to face in the past and to a certain extent still have to face today. During the creative development process, the two writers of the piece conducted interviews with community members and their statements were presented verbatim in the piece. In some songs their vernacular language and Melanesian musical styles were used to create a deeper sense of connection with the story. The work was very emotional and confronting for both participants and audience members, but the community felt proud of their ancestors and that their story was told. The work therefore met one of the key social benefits of community cultural development programmes identified by Mulligan and Smith (2006: 49), as it helped 'to locate and/or retain stories from the past that can give a local community a deeper sense of belonging.'

The piece was put together by two writers, two composers, a director, a designer, and a production and technical team on the ground (all contracted by QMF). The QMF core staff was also involved in the creative process over the three years and made several trips to Bowen. The entire production team then moved to Bowen approximately two months before the show and from then rehearsals took place every day. According to the festival organisers and production team, dealing with an entirely non-professional cast was a challenge at times, as people had other jobs or duties and often could not 
make it to rehearsals. However, the QMF team kept emphasising that rather than a perfect show in the end, it was the process of working together with the community, empowering them and teaching them new skills that mattered the most, as well as making sure their stories were suitably and honestly told (personal communication).

The three performances on 28, 29 and 30 July 2011 were free and presented at the Bowen Soundshell which features an outdoor stage at the foreshore. There were approximately 120 people on stage for each performance: a band, choir, children's choir, as well as several actors and dancers. Over the three nights, there was a total audience of about 8,000 people coming not only from Bowen but also surrounding towns, such as Proserpine, Ayr and Mackay to witness the performance, a lot of them were South Sea Islanders (personal information, QMF).

\section{Methodology}

This study is part of a bigger PhD project about power, knowledge and knowledge management in music festival organisations. Through taking a post-structuralist approach I aimed to understand festival staff members' perceptions and meanings of power and knowledge within the concepts available to them (Townley, 1993; Alvesson, 1996; Kaufmann, 2011). A reflexive ethnographic study was undertaken in order to understand these different meanings and changes in perception over the course of the festival life cycle. Reflexivity means looking at one's own assumptions about power and knowledge and being self-critical as interpreter and author as well as critically thinking and reflecting on the context and conditions for what one is doing, and acknowledging that the researcher's own background and beliefs are part of this reflection (Holland, 
1999; Alvesson \& Skoeldberg, 2000; Snape \& Spencer, 2003; Davies, 2008). It also means reflecting on the relationship between researcher and participant (Finlay, 2002) and recognising that this research is co-constituted with the Queensland Music Festival. I therefore interpreted and re-interpreted my own insights and experiences as well as made multiple 'voices' heard about the perceptions of power and knowledge. Alvesson and Skoeldberg (2000: 187) emphasised that, '[i]t is important to consider not only or mainly the dominant, but also and especially the marginal. (...) The ideal of pluralism may mean that the phenomenon is looked at from various angles'. The approach provided a detailed account of the issue under study and at the same time by contrasting different, or even contradicting perspectives, it was possible to see multiple realities without claiming that one of them is the only 'truth' (Saukko, 2003).

For my reflexive ethnographic study, I spent time with the QMF festival organisation as a case study in the lead-up, as well as during and several weeks after the 2011 festival season. In case study research, the researcher may choose one or several cases within the bigger case under study (Yin, 2009). I therefore chose Behind the Cane as a smaller case within my case study of QMF and made two trips to Bowen to take a closer look at the Behind the Cane project: one during the rehearsal period in June 2011, and another for the performances in July 2011. During those two weeks I spent time with the team on the ground, participated in meetings and helped out with small jobs during and after rehearsals. I wrote field notes after all observations, in which I described the setting and key events, the participants and their roles, several informal talks with festival and community members, and I also focused on sometimes different stories that I heard about the same events (Emerson, Fretz, \& Shaw, 1995; Davies, 2008). Through this immersion in the festival experience not only in Bowen but also at the festival head- 
quarters in Brisbane I gained an understanding of the festival and its community cultural development focus and how Behind the Cane fitted into the broader festival context.

I also conducted 28 in-depth interviews; seven of them were with festival members associated with Behind the Cane, both in Bowen as well as at the festival headquarters in Brisbane. Some were interviewed before the festival, others during or after the festival to identify changes in meaning and perception over the course of the festival life cycle. Especially the interviews that occurred shortly before or after the performances displayed the excitement of the people involved. Participation was completely voluntary. The interviews lasted for approximately 45-60 minutes and were recorded using a digital voice recorder. In the interviews I asked questions about the participants' background and experience in community cultural development, the QMF in general and the history and creative development process of Behind the Cane in particular. All interviews were transcribed verbatim and for this article, stories about the Behind the Cane project were identified and analysed in their context.

Lewis (2011: 505) argued that, '[s]tory is central to human understanding-it makes life livable, because without a story, there is no identity, no self, no other. (...) It is through genuine repetition, storytelling, that humans narrate ways of knowing and being.' In stories, therefore, my participants expressed the power relations within and the meaning of the Behind the Cane project to themselves, to the festival team and the community from their subject positions. Subject positions are 'social spaces from which agents are able to act' (Oborn \& Dawson, 2010: 1853) and legitimise these agents' activities and actions. I focus on three participants and some of their stories below. The three participants whose stories I have chosen had very different levels of involvement with the 
show as well as with the festival organisation and therefore provided different views on the topic (Rubin \& Rubin, 2005). Furthermore, stories and narratives given in an interview may differ from those told in day-to-day conversation (Cortazzi, 2001). I therefore chose two stories that were told as part of interviews and one that I heard in an informal conversation and later summarised in my field notes. Rather than claiming that one of them told the 'truth', I aimed for different perspectives and perceptions of the same topic:

- Greg was a member of the creative team. He is highly experienced in community cultural development and has been involved with the project for more than a year. Greg was contracted by the festival organisation and moved to Bowen for several weeks to help build the show. He was interviewed six weeks before the show and then again on the day after the first performance.

- Nathan is a local from Bowen. He is not directly associated with QMF, but works for the regional council and was therefore an important point of call for the festival staff. He was interviewed after the first performance.

- Elizabeth is a direct South Sea Islander descendant and member of the community. She lives in Bowen and was singing in the choir. Elizabeth did not want to do an interview, but told me a lot of stories in several informal talks during and after rehearsals which I summarised in my field notes.

Ethical approval for the study has been obtained from the Griffith Human Ethics Committee and all protocols have been followed. All participants were informed about the research and the researcher's presence before, during and after the festival. Names in the stories below have been changed. Interview transcripts were sent back to those par- 
ticipants who wished to see them; one of them asked for minor changes and clarifications.

Stories and narratives represent the character and perceptions of certain subgroups in society and can be used to identify otherwise unheard voices (Lieblich, TuvalMashiach, \& Zilber, 1998). A narrative analysis therefore provided insights into not only the festival managers' perceptions of power and knowledge but also the community's. In analysing the stories I followed a holistic-content narrative analysis approach (Lieblich, et al., 1998). I read and re-read the interview transcripts and field notes in their entirety several times in order to understand the meaning of the text and to identify themes as well as issues not talked about. Within each text stories can be identified through a change in the amount of detail that participants go into in telling these stories as well as a description of certain events with a clear beginning and end and evaluation of the significance of these events for participants (Riessman, 1993; Franzosi, 1998). Unfortunately due to space restrictions the interview transcripts and field notes cannot be presented in their entirety below, however, I will provide to the reader a summary of the context in which the stories were told. Especially in narrative analysis it is important to make the research process visible in order to achieve trustworthiness and credibility (Bailey, 1996).

There are further limitations that need to be acknowledged. First, storytelling is influenced by social factors such as the participants' knowledge of the research and researcher role and thus an awareness of the audience for their stories (Cortazzi, 2001; Thomas, Kellog, \& Erickson, 2001). In stories, the storyteller also aims to make a point and therefore may at times exaggerate to achieve a special effect (Rubin \& Rubin, 
2005). Furthermore, it needs to be taken into account that the participants only told me as much as they felt comfortable with and there were certain issues they did not want to elaborate on. Through my ethnographic research approach, however, I gained an understanding of the broader context and importance of this project which helped in reflecting upon and understanding my participants' stories and the way they told these stories (Alvesson \& Skoeldberg, 2000; Fleming \& Fullagar, 2007).

\section{Stories and Findings}

The stories and findings below emphasise power relations during the creative development process of Behind the Cane, and the naming of the piece in particular. I will also deal with the power of the story and performance itself and what it meant to the South Sea Islander community as well as the festival organisers. From these stories I will explain how new knowledge was created within the Bowen community and the QMF organisation.

In order to be able to work together with a community, the QMF festival staff have learned over time that the first step in putting together a successful community cultural development project is building strong relationships with certain community members and in the Behind the Cane case particularly with the elders, as Greg in his position as a QMF representative explained to me. Greg first talked about the community cultural development principles that QMF employs in general and then went into great detail when he told me the story of how they first met with the elders in Bowen and informed them about the project:

First thing that has to happen is to have the community approve of it! And that goes through people like $[\ldots]$ or $[\ldots]$, the elders in this particular community. We 
sort of sit in front of them and say 'okay, fellas... this is what we have, this is what we're going to do, this is the story, the set...' and we tell them the story and play them the songs. And they sit there with their eyes closed and arms fold, listening very carefully and then they go 'okay that sounds good... Is this going to happen?!' And we confirm, 'yeah, it's going to happen!' (laughs) And again, 'oh, good...' (nodding) So that's kind of an ongoing process. You can see the friendships that we've developed are the most important thing. And the rule number one is to keep everybody safe. And that's not just about physical safety, that's about making sure that the stories are safe and to make this a wonderful experience for individuals, for the story, for the community. You know, that we just make it fun. So there's never... we try to... well, it is what it is! And sometimes it might not actually fit with what people regard as a professional performance, but it will have its own authority and its own authenticity and its deep connection. That's all that counts, okay? We can't expect them to do anything more than that. And they don't need to do more than that. (interview Greg)

In this story, Greg described what happens when QMF staff members first approach a community and explain their ideas to them. He then highlighted the importance of this process and made sure I understood the point of his story through summarising that not only does QMF have to build the necessary relationships and trust among the community, but they also have to ensure that the participants' stories are told in an honest way and that the community approves of all stories. He concluded his story by emphasising that this approach brought about an authentic piece in its own right, a piece through which not only the community could enhance their performance skills and learn about their ancestors, but also the audience and festival attendees. 
Relations of power organise and situate organisational practices (Brown, Kornberger, Clegg, \& Carter, 2010). Within QMF, these relations of power therefore influence the creative development practice that the festival organisation employs in working with communities. At times, the QMF strategy of working with the community can pose challenges for the festival organisation. One example of such a challenge was the choice of a suitable title for the project. After a lengthy general discussion about the principles and values of QMF, about how they work and collaborate with the community, Greg told me about this particular issue:

They [QMF] wanted to call this thing Blackbirding and the community didn't want that. So there was a bit of a stand-off. [A QMF representative] had a meeting with the community and they told her, 'no not under these terms!' The project would not go forward if it has that title! (...) And I said, 'hey, we made a commitment to these people to listen to them and to stand by them. I made that commitment and Jenny made that commitment too, alright. And we are your representatives! So if we've made that commitment to them, the promises that we've made, are yours. And so going against that, you would break that promise that Jenny and I have made. I am not going to break my promise with those people, the people who gave us their story! I'm not going to do that! I can't do it, I would have to quit.' I think she got that... she left a message after that, saying 'yeah, it would have been a great title for the QMF, but it's not about us.' And eventually they came up with a really good title. And it's all good now. (...) I think it's just a process you go through, but it was... it came right down to the very basic reason why we are doing this! And you need to stand by your promises and the very reason why we are here in the first place, and why they allowed us to use their story and all that stuff. It came right down to that QMF versus the community. And we stood by them, so it's good. (interview Greg) 
Greg started this story with a brief introduction about the problem. Then he went into great detail in describing what happened. He got quite emotional while telling this story, started to talk faster as he told what exactly he said in this situation and then abruptly stopped after saying 'I would have to quit.' As if he wanted to make the point very clear, he almost whispered the following 'I think she got that...' before moving on to his conclusion of why this process was important to go through. Greg highlighted the conflict that arose between the desires of QMF and those of the community. Organisations can be trapped within the strategic power of their own cultural values (Alvesson, 1996), and in this case, QMF was clearly trapped within the strategic power of their creative development process that emphasises collaboration with the community and had to back down and listen to what the community wanted. The shift in power relations from the festival team to the community led to a learning process for both sides: QMF was reaffirmed that their strategy of working with the community rather than imposing ideas upon them was crucial in maintaining a good relationship and creating a successful piece. The community, on the other hand, learned that their input was regarded as valuable and important at all times. This constructive use of power (Foucault, 1980, 1982), therefore, created new knowledge for participants involved with the project.

Presenting a new work about a challenging historic topic also meant that the story $B e$ hind the Cane itself was quite powerful. The South Sea Islander community told their own story and acknowledged their ancestors. As argued earlier, in community cultural development projects the community needs to feel ownership of the piece (Kay, 2000), which in the case of Behind the Cane was achieved through collecting stories from interviews with South Sea Islanders and incorporating them verbatim into the script. During an informal conversation I had with Elizabeth over coffee, she started telling me 
about different stories that ended up in the script. She was quite excited when she got to her favourite story and we both shared a laugh:

QMF then, together with Elizabeth and the elders, started collecting stories from community members and ancestors. For example, Elizabeth tells me about the love story ('She's Got Her Eye On You') between a 'white' man and a South Sea Islander woman within the piece. This love story is real. It took place on the cricket field after a game and the man who this story is about actually is now also engaged in the project. When the writers first presented the script, he realised that it was the story of how he and his wife met. Apparently he turned red like a tomato. But now he loves it, he is proud to be in the show and proud that his own story is told. Elizabeth loves telling that story too, she just can't stop laughing when she describes the situation of the man blushing. (field notes, 28/06/11)

Not only did Elizabeth enjoy telling this story, it was also important to her to use the story as an example of how the community was involved in creating the piece and their emotional attachment to the project. She summarised her point by saying that that's what makes QMF so special. They don't mind putting themselves in the background. It's not about how big or how great QMF is, or what kinds of shows they have lined up. No, it's all about what the community wants (field notes, 28/06/11). Even though another cast member performed the song and scene around this story on stage, the man felt proud that his story was told and part of such an important work for the community. Through incorporating this story into the work, the audience and festival attendees got a taste of what it felt like for a 'white' man to fall in love with a South Sea Islander woman. The story itself was short and within the entire piece seemed rather insignificant; however, it was powerful in its own right and created new knowledge for the South Sea Islander community as well as festival participants. 
Because of the power of the story and the delicate process that QMF engaged in putting the piece together, the local community fully supported the project and QMF. Nathan initially told me that the South Sea Islander community in Bowen is rather quiet and usually remain in the background, but he later got very excited when he told me about the community support of the project and having the entire town talking positively about the event. He also emphasised that QMF quickly realised the success of the event and that they had to create more room to accommodate a larger crowd:

I was happy about the local support of it. Jenny said to me on the rehearsal on Wednesday night, before that she said to me, 'Nathan, are people going to come?! Is it out there?' And I said, 'Jenny, it's out there! EVERYBODY is talking about this show!' And I suppose you do get those concerns and I had that a little bit too, but I knew people would turn up. It's a great show. And if a hundred people show up... whatever! It's not about the quantity of people who turn up; it's not about a million people seeing it! It's about what the story really means to people who actually see it. And you know, the biggest problem we had last night was the room. We just didn't have enough room! (...) It's too closed in with the grand stand and all that... So when I went in this morning, the grand stands have been moved back, so that the area grew. (interview Nathan)

In this story, Nathan briefly told what happened on Wednesday night when he had a chat with one of the QMF representatives, then provided a more general comment on why the amount of people coming to the show was not important but rather what the story meant to the community. To counter his point, however, he then enthusiastically went back to talking about what actually happened on the night ('We just didn't have enough room!') and how the QMF staff dealt with the issue of having a larger crowd 
than expected. The technical team quickly learned that they needed to create more room for the audience for the second and third performance. Having the entire town of Bowen talk positively about the project shows in part how successful and well supported by the local community it was.

\section{Discussion}

In the above stories I have identified that the QMF exercised strategic and disciplinary power in engaging with the South Sea Islander community in order to build a work with them. This strategy has been learned within the organisation over time and continues to be reaffirmed and altered through each new project they commission. Thus, for the festival organisation new knowledge is created through every new piece and the various power relations around them (Brown, et al., 2010). The naming of the piece, for example, was a particular challenge in the Behind the Cane project for the staff and a moment to realise that their strategy of working with the community rather than imposing ideas upon them can lead to conflict. However, a shift in power balance (Cole, 2006) occurred when the festival team let go of their idea and valued the community's input in the naming of the piece. The constructive use of power, therefore, reaffirmed the QMF cultural values and enhanced the festival staff members' understanding and learning about the South Sea Islander community in Bowen, which in turn will be useful for future projects with other communities in Queensland.

At the same time, the South Sea Islander community learned that they could exercise strategic power as well and that they had the opportunity to influence the creative development process of the piece at any point in time. They learned that QMF emphasises 
making marginalised voices heard and that it was their story they wanted to tell, rather than the festival organisers' version of the story. The empowering process was essential for the community to feel ownership of the piece and to feel proud of their ancestors, and thus fulfilled an important principle of community cultural development projects (Kay, 2000; Adam \& Goldbard, 2001; Mulligan \& Smith, 2006; Hager, 2008). For QMF, at the same time, it was important to go into the development process of the piece 'without knowing anything' and letting the South Sea Islander community be the voice of the piece. In terms of power/knowledge relations, the shared development of knowledge was thus crucial for 'the self-definition of the subjects as subordinates in relation to this knowledge' (Alvesson, 1996: 122), and reaffirmed the QMF strategy of not simply exercising power 'over' the community.

Finally, the power of the story itself, its focus on a controversial historic topic, must not be neglected. Through the presentation of this story, the QMF aimed to deal with a part of the Australian history that is usually not talked about or at the most from a 'white' man's perspective. Hardly ever is the South Sea Islander descendants' version of the story mentioned (Wawn, 1973). In engaging with the community, however, it turned out that they did not hold any negative feelings anymore. They were ready to move on and wanted the piece to end on a positive note. Nevertheless, the performance was emotional and moving for not only participants but also the audience - both South Sea Islanders and 'white' audience members. The power of the story thus provided an opportunity to learn about the past of these families and to build a new understanding through telling their version of the story. At the same time, the story disciplined the discursive practices of the creative development process. Having the support of the community to create the piece together and to get them excited about it, further led to a successful performance 
for the QMF - with a much larger audience than originally anticipated - in what essentially was a rather risky undertaking.

\section{Conclusion}

In the stories my participants told, power/knowledge relations in developing the Behind the Cane project were identified. I have shown that through several shifts in power balance and the constructive use of power as well as through the challenge of finding an appropriate title for the piece, new knowledge was created for both sides despite the occasional conflicts. The principle of partnering with the community during the development process (Kay, 2000; Martin, et al., 2000; Adam \& Goldbard, 2001; Mulligan \& Smith, 2006; Hager, 2008) was thus followed by the festival organisation and ensured the South Sea Islander community 'owned' the piece. Sharing the experience of working on the project over several months/years as well as the experience of the performance itself were vital aspects of engaging the local community. The process of making music together rather than merely the performance in the end can have a key function in terms of creating a sense of identity among the community (Bennett, 2005; Pitts, 2005). Especially during the Behind the Cane rehearsal period, friendships were formed, skills were developed and the social dimension of making music together and building the performance were experienced by participants and the team.

The power of the story itself was crucial in gaining the community's approval and building a shared discourse. Even though a controversial historic topic was chosen, the community supported the project as the festival organisation ensured an honest representation of their story. Participants were proud to be part of the show as well as of their 
ancestors and families. This was possible through a delicate dealing with the issue (e.g., double-checking the interviews with community members before using direct quotes in the script) and an awareness of the power of the story among the festival staff. Ultimately, extending Casbeard's (2010: 155) argument of 'inclusion' and 'denial', the project aimed for better 'inclusion' of the South Sea Islander community in Bowen and defeated the notion of 'denial' of the 'blackbirding' practice in Queensland. I have thus shown that through the constructive use of power, an honest representation of the community's story was achieved and experienced by community members, the festival staff and the audience. The QMF staff has with Behind the Cane gained new knowledge on what is possible and achievable through their projects. The newly created knowledge can be shared through telling and re-telling the stories to new staff members, a process through which it is possible for organisations to create an organisational memory system (Boje, 1991).

Festival organisers and practitioners involved with community cultural development projects need to understand the complexities of working with a community over an extended period of time. Clarke and Jepson (2011: 16) argued that 'the exercise of power needs to be carefully explored' in the management of festivals. Community cultural development principles in particular require the organisers at times to step back and let the community be the 'voice'. While the festival organisation therefore provides the framework for these pieces, the community needs to provide the 'story'. I have shown that working in partnership is more beneficial than exercising power 'over' the community and imposing ideas upon them. Staff members need to understand and embrace these processes and practices of working with the community, practices that need to be developed over a long period of time rather than merely during the stressful lead-up to the 
festival season. Continuity within the festival organisation as well as consistency in communicating with community participants is therefore crucial for the long-term success of these projects (Phipps \& Slater, 2010). The social outcomes of community cultural development projects in turn not only benefit the community, but also the festival organisation in terms of learning new ways of working together, collaboration among the staff as well as a deep connection with the culture and values of the festival organisation.

\section{Acknowledgements}

I would like to thank the Queensland Music Festival and Behind the Cane team for supporting my research project. 


\section{References}

Adam, D., \& Goldbard, A. (2001). Creative Community - The Art of Cultural Development. New York: The Rockefeller Foundation.

Alvesson, M. (1996). Communication, Power and Organization. Berlin and New York: Walter de Gruyter.

Alvesson, M., \& Skoeldberg, K. (2000). Reflexive Methodology - New Vistas for Qualitative Research. London/Thousand Oaks/New Delhi: SAGE Publications.

Australia Council for the Arts (2010). More than bums on seats: Australian participation in the arts, Sydney, http://www.apo.org.au/sites/default/files/Full_ report_More_than_bums_on_seats_Australian_participation_in_the_arts.pdf (accessed 10 June 2011).

Bailey, P. H. (1996). Assuring Quality in Narrative Analysis. Western Journal of Nursing Research, 18(2), 186-194.

Bartleet, B.-L., Dunbar-Hall, P., Letts, R., \& Schippers, H. (2010). Sound Links Community Music in Australia, Queensland Conservatorium, Griffith University, Brisbane, http://www.griffith.edu.au/music/queenslandconservatorium-research-centre/resources/sound-links-final-report (accessed 8 February 2011).

Bennett, A. (2005). Culture and Everyday Life. London/Thousand Oaks/New Delhi: SAGE Publications.

Bevir, M. (1999). Foucault, Power and Institutions. Political Studies, XLVII, 345-359. Boje, D. M. (1991). The Storytelling Organization:A Study of Story Performance in an Office-Supply Firm. Administrative Science Quarterly, 36(1), 106-126. 
Bramham, P. (1994). Community Arts. In L. Haywood (Ed.), Community Leisure and Recreation - Theory and practice (pp. 83-110). Oxford: Butterworth Heinemann.

Brown, A. D., Kornberger, M., Clegg, S. R., \& Carter, C. (2010). 'Invisible walls' and 'silent hierarchies': A case study of power relations in an architecture firm. Human Relations, 63(4), 525-549.

Carey, P., \& Sutton, S. (2004). Community development through participatory arts: Lessons learned from a community arts and regeneration project in South Liverpool. Community Development Journal, 39(2), 123-134.

Casbeard, R. (2010). Slavery Heritage in Bristol: History, memory and forgetting. Annals of Leisure Research, 13(1-2), 143-166.

Clarke, A., \& Jepson, A. (2011). Power and hegemony within a community festival. International Journal of Event and Festival Management, 2(1), 7-19.

Clegg, S. (1998). Foucault, Power and Organizations. In A. McKinlay \& K. Starkey (Eds.), Foucault, Management and Organization Theory - From Panopticon to Technologies of Self (pp. 29-48). London/Thousand Oaks/New Delhi: SAGE Publications.

Cohen, S. (1995). Sounding out the city: music and the sensuous production of place. Transactions of the Institue of British Geographers, 20(4), 434-446.

Colbert, E. (1997). The Pacific Islands - Paths to the Present. Boulder and Oxford: Westview Press.

Cole, S. (2006). Cultural Tourism, Community Participation and Empowerment. In M. Smith \& M. Robinson (Eds.), Cultural Tourism in a Changing World - Politics, Participation and (Re)presentation (pp. 89-103). Clevedon, Buffalo, Toronto: Channel View Publications. 
Cortazzi, M. (2001). Narrative Analysis in Ethnography. In P. Atkinson, A. Coffey, S. Delamont, J. Lofland \& L. Lofland (Eds.), Handbook of Ethnography (pp. 384394). London/Thousand Oaks/New Delhi: SAGE Publications.

Davies, C. A. (2008). Reflexive Ethnography - A Guide To Researching Selves And Others (2nd ed.). London and New York: Routledge.

Derrett, R. (2003). Festivals \& Regional Destinations: How Festivals Demonstrate a Sense of Community \& Place. Rural Society, 13, 35-53.

Docker, E. W. (1970). The Blackbirders - The Recruiting of South Seas Labour for Queensland, 1863-1907. Sydney et al.: Angus \& Robertson.

Duffy, M., \& Waitt, G. (2011). Rural Festivals and Processes of Belonging. In C. Gibson \& J. Connell (Eds.), Festival Places - Revitalising Rural Australia (pp. 44-57). Bristol, Buffalo, Toronto: Channel View Publications.

Emerson, R. M., Fretz, R. I., \& Shaw, L. L. (1995). Writing Ethnographic Fieldnotes. Chicago and London: The University of Chicago Press.

Finlay, L. (2002). Negotiating the swamp: the opportunity and challenge of reflexivity in research practice. Qualitative Research, 2(2), 209-230.

Fleming, C., \& Fullagar, S. (2007). Reflexive Methodologies: An autoethnography of the gendered performance of sport/management. Annals of Leisure Research, 10(3-4), 238-256.

Foucault, M. (1977). Discipline and Punish - The Birth of the Prison (A. Sheridan, Trans.). New York: Pantheon Books.

Foucault, M. (1978). The Will to Knowledge - The History of Sexuality, Volume 1 (R. Hurley, Trans.). London et al.: Penguin Books.

Foucault, M. (1980). Power/Knowledge - Selected Interviews \& Other Writings 19721977 (edited by Colin Gordon). New York: Pantheon Books. 
Foucault, M. (1982). The Subject and Power. Critical Inquiry, 8(4), 777-795.

Franzosi, R. (1998). Narrative Analysis-Or Why (And How) Sociologists Should be Interested in Narrative. Annual Review of Sociology, 24, 517-554.

Getz, D. (2007). Event Studies - Theory, research and policy for planned events. Amsterdam et al.: Butterworth-Heinemann.

Gibson, C., Connell, J., Waitt, G., \& Walmsley, J. (2011). The Extent and Significance of Rural Festivals. In C. Gibson \& J. Connell (Eds.), Festival Places Revitalising Rural Australia (pp. 3-24). Bristol, Buffalo, Toronto: Channel View Publications.

Gibson, C., \& Connell, J. (2012). Music Festivals and Regional Development in Australia. Farnham and Burlington: Ashgate.

Graves, A. (1993). Cane and Labour - The Political Economy of the Queensland Sugar Industry, 1862-1906. Edinburgh: Edinburgh University Press.

Hager, L. L. (2008). Community Arts. In G. Carpenter \& D. Blandy (Eds.), Arts and Cultural Programming - A Leisure Perspective (pp. 159-172). Champaign et al.: Human Kinetics.

Hawkins, G. (1991). Reading Community Arts Policy: From Nimbin to the Gay Mardi Gras. In V. Binns (Ed.), Community and the Arts - History, Theory, Practice (pp. 45-54). Leichhardt: Pluto Press Australia Ltd.

Hoffie, P. (1991). Centres and Peripheries. In V. Binns (Ed.), Community and the Arts History, Theory, Practice (pp. 31-44). Leichhardt: Pluto Press Australia Ltd.

Holland, R. (1999). Reflexivity. Human Relations, 52(4), 463-484.

Hull, A. (1991). Patronage. In V. Binns (Ed.), Community and the Arts - History, Theory, Practice (pp. 135-146). Leichhardt: Pluto Press Australia Ltd. 
Johnson, A. J., Glover, T. D., \& Yuen, F. C. (2009). Supporting effective community representation: Lessons from the Festival of Neighbourhoods. Managing Leisure, 14(1), 1-16.

Kaufmann, J. (2011). Poststructural Analysis: Analyzing Empirical Matter for New Meanings. Qualitative Inquiry, 17(2), 148-154.

Kay, A. (2000). Art and community development: the role the arts have in regenerating communities. Community Development Journal, 35(4), 414-424.

Kirby, S. (1991). An Historical Perspective on the Community Arts Movement. In V. Binns (Ed.), Community and the Arts - History, Theory, Practice (pp. 19-30). Leichhardt: Pluto Press Australia Ltd.

Lancaster, H., Kyte, S., Craik, J., \& Schippers, H. (2010). Redefining Places for Art Exploring the dynamics of performance and location (report), Queensland Conservatorium, Griffith University, Brisbane, http://www.griffith.edu.au/ music/queensland-conservatorium-research-centre/resources/redefining-placesfor-art (accessed 8 February 2011).

Lewis, P. J. (2011). Storytelling as Research/Research as Storytelling. Qualitative Inquiry, 17(6), 505-510.

Lieblich, A., Tuval-Mashiach, R., \& Zilber, T. (1998). Narrative Reserach - Reading, Analysis, and Interpretation. Thousand Oaks/London/New Delhi: SAGE Publications.

Martin, D., Tunny, K., \& Carroli, L. (2000). Community Cultural Development - A Guide: A resource for artsworkers in Queensland. New Farm: Queensland Community Arts Network.

Molloy, J. (2002). Regional Festivals: A look at community support, the isolation factor and funding sources. The Journal of Tourism Studies, 13(2), 2-15. 
Mulligan, M., \& Smith, P. (2006). Stepping Out of the Shadows of Neglect - Towards an understanding of socially applied community art in Australia. International Journal of the Arts in Society, 1(4), 43-52.

O'Rourke, S., Irwin, D., \& Straker, J. (2011). Dancing to sustainable tunes: an exploration of music festivals and sustainable practices in Aotearoa. Annals of Leisure Research, 14(4), 341-354.

Oborn, E., \& Dawson, S. (2010). Knowledge and practice in multidisciplinary teams: Struggle, accommodation and priviledge. Human Relations, 63(12), 1835-1857. Phipps, P. (2011). Performing Culture as Political Strategy: The Garma Festival, Northeast Arnhem Land. In C. Gibson \& J. Connell (Eds.), Festival Places Revitalising Rural Australia (pp. 109-122). Bristol, Buffalo, Toronto: Channel View Publications.

Phipps, P., \& Slater, L. (2010). Indigenous Cultural Festivals - Evaluating Impact on Community Health and Wellbeing, Globalism Research Centre, RMIT University, Melbourne, http://mams.rmit.edu.au/ufwg124fk6adz.pdf (accessed 12 September 2012).

Pitts, S. E. (2005). Valuing Musical Participation. Aldershot: Ashgate.

QMF. (2011) Queensland Music Festival, http://qmf.org.au/ (accessed 20 September 2011).

Reid, S. (2008). Identifying Social Consequences or Rural Events. Event Management, $11,89-98$.

Riessman, C. K. (1993). Narrative Analysis. Newbury Park, London, New Delhi: SAGE Publications.

Rogers, P., \& Anastasiadou, C. (2011). Community Involvement in Festivals: Exploring Ways of Increasing Local Participation. Event Management, 15(387-399). 
Rouse, J. (2006). Power/Knowledge. In G. Gutting (Ed.), The Cambridge Companion to Foucault (2nd ed., pp. 95-122). Cambridge et al.: Cambridge University Press. Rubin, H. J., \& Rubin, I. S. (2005). Qualitative Interviewing - The Art of Hearing Data (2nd ed.). Thousand Oaks/London/New Delhi: SAGE Publications.

Saukko, P. (2003). Doing Research in Cultural Studies - An introduction to classical and new methodological approaches. London/Thousand Oaks/New Delhi: SAGE Publications.

Sinclair, J. (2005). The Impact of Stories. The Electronic Journal of Knowledge Management, 3(1), 53-64.

Slater, L. (2011). 'Our Spirits Arise from the Ashes': Mapoon Festival and History's Shadow. In C. Gibson \& J. Connell (Eds.), Festival Places - Revitalising Rural Australia (pp. 123-135). Bristol, Buffalo, Toronto: Channel View Publications.

Snape, D., \& Spencer, L. (2003). The Foundations of Qualitative Research. In J. Ritchie \& J. Lewis (Eds.), Qualitative Research Practice: A Guide for Social Science Students and Researchers (pp. 1-23). London/Thousand Oaks/New Delhi: SAGE Publications.

Sonn, C. C., Drew, N. M., \& Kasat, P. (2002). Conceptualising Community Cultural Development: The Role of Cultural Planning in Community Change Perth: Community Arts Network WA Inc.

Thomas, J. C., Kellog, W. A., \& Erickson, T. (2001). The knowledge management puzzle: Human and social factors in knowledge management. IBM Systems Journal, 40(4), 863-884.

Townley, B. (1993). Foucault, Power/Knowledge and Its Relevance for Human Resource Management. Academy of Management, 18(3), 518-545. 
Wawn, W. T. (1973). The South Sea Islanders and the Queensland Labour Trade.

Canberra: Australian National University Press.

Yin, R. K. (2009). Case Study Research - Design and Methods (4th ed.). Los Angeles et al.: SAGE. 